\title{
進化遺伝学
}

\section{Mammoth genomics}

\section{マンモスのゲノミクス}

\section{Michael Hofreiter}

Nature Vol.456 (330-331)/20 November 2008

マンモスのゲノム塩基配列の大半が再構築された。こうした研究は、絶滅した種の生物学的特徵や進化の解明に大い に役立つにちがいない。

時代は変わるものだ。哺乳類のゲノムの塩基配列を決定する 作業（シーケンシング）は、高速処理技術が開発されたおか げで大きく様変わりした。当初は数年を要する数百万ドル規 模の一大事業だったのが、10 年足らずのうちに、1 つの研 究室で数か月以内に完了できるようになったのである。その 進歩はめざましく、今では、絶滅したマンモスの核ゲノムの 塩基配列を、ほぼ完全に決定することさえ可能になった。

Miller たちは今回、その成果を Nature 2008 年 11 月 20 号のp.387 に報告した ${ }^{1}$ 。これまでの研究で、ミトコンド リア由来のマンモス DNA については、既に塩基配列が解 読されている（細胞内小器官であるミトコンドリアには、 独自に小さいゲノムが備わっている)。しかし、マンモスの 細胞核ゲノムは 40 ～ 50 億塩基対あって、ミトコンドリア DNA よりずっと大きく、生物学的情報もはるかに多く含ま れており、これを解読することは桁違いの難題だった。

およそ 10 万年も前の化石から得られる古代 DNA は、非 常に細かく断片化していて、ごくわずかしか存在しておらず、

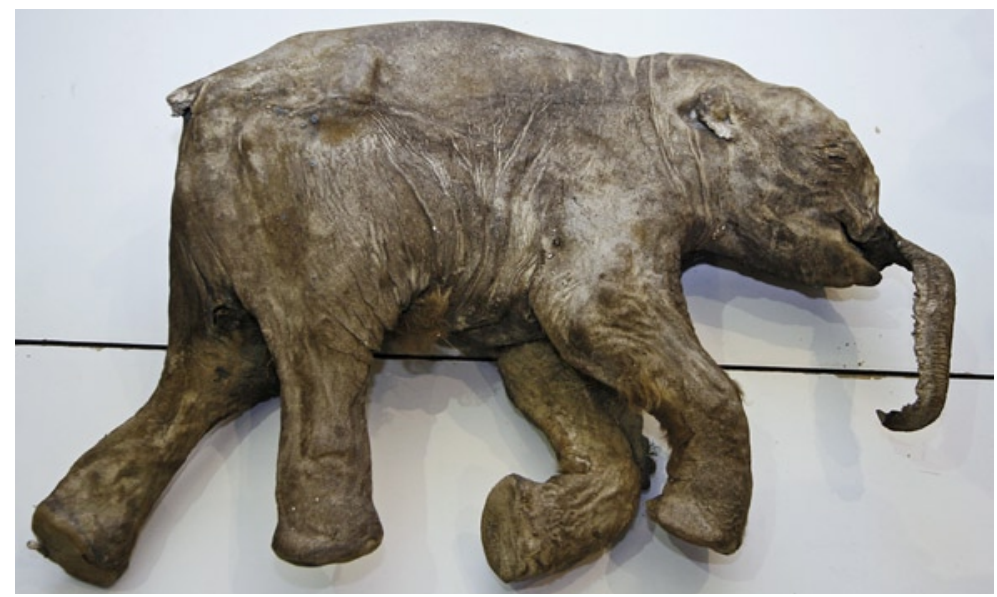

2007 年 5 月、西シベリアのユリベイ川付近で、約 3 万 7000 年前に絶命したとみら れる、生後約半年の雌の凍結マンモスが発見された。「リューバ」と名づけられたこの マンモスは、全身が非常に良好な保存状態で残り、今後の解析に大きな期待が寄せら れている。
そのうえ細菌や菌類の DNA にまみれているのが普通であ る。そのため、絶滅した生物種の全ゲノム塩基配列を読み取 るなどということは、かつては到底思いもつかなかつた。と いうのも、30 年ほど前から大規模な塩基配列決定法として 唯一使うことのできたサンガー法 ${ }^{2}$ は、こうした古代 DNA 解析に適していなかったからである。しかし 2005 年に なって、新しい DNA 塩基配列決定法が報告された ${ }^{3}$ 。これ は454 法とよばれるもので、開発当初のシーケンシング能 力でも 1 回当たり 2000 万塩基対と、サンガー法の 100 1000 倍になった。その後、シーケンシング能力は 1 回当た り約 1 億塩基対まで向上し、またほかに、Solexa、SOLiD、 HeliScope という 3 種類の塩基配列決定法も登場した。こ れらの手法では、1 回につき 100 億塩基対もの配列データ が得られる。しかしこれらはすべて、「ショットガン」法と よばれる方法で、シーケンスできる塩基配列は短く、エラー 率が極めて高い場合もある。そのため、個々のヌクレオチド 部位についての信頼度が高い塩基配列を得るには、ゲノムを 高いカバー率で幾重にも読み取る必要がある。Miller たちの 試算では、今後マンモスの核 DNA についてさらに高い精度 で塩基配列を決定するには、およそ 10 ～ 20 倍のカバー率 が必要だろうという。シーケンシング能力が急速に向上して いることを踏まえると、これもまもなく達成できるだろう。

こうした進歩によって、分子遺伝学についての考え方も変 わり、絶滅種のゲノムを最終的にどうやって解明すればよい かも明らかになった。大事なことは、現生生物の DNA を研 究するうえでは短所となる新手法のいくつかの側面が、古代 DNA を対象とする場合には長所になるということだ。サン ガー法は 1 回の反応で、最大 800 塩基対の個々の DNA 鎖 を配列決定できるが、新手法ではもつと短く、ときには 30 塩基対程度しか調べることができない 4 。これは、現生生物 の DNA を調べる場合には短所となる。しかし、古代 DNA はそのほとんどが 100 塩基対以下の短い断片になっている ので、問題とならないのである。 
研究者たちはすぐに、こうした新しい可能性を有効活用し た。454 法は、利用できるようになってからわずか数か月で、 マンモスのゲノム解析に適用され、論文が発表されたのだ ${ }^{5}$ 。 そこに報告されたのは 1300 万塩基対の配列で、これはサン ガー法による最初の古代ゲノム解析研究 ${ }^{6}$ で対象範囲となつ た配列の、約 1000 倍以上にあたる。2006 年 1 月に発表さ れたこの論文 ${ }^{5}$ では、論文著者たちが、マンモスの全ゲノム の塩基配列決定も計画していることを明言していた。Miller たち ${ }^{1}$ は今回、マンモスのゲノムのおよそ $70 \%$ について報 告しており、全ゲノム解読という目標を達成するために大き な貢献をしたことになる。

Miller たちにとって、配列決定の際に非常に助かったのは、 絶滅生物にしては珍しいことに、マンモスの化石標本の一部 が永久凍土層内で凍っていたことである。これはDNAの保 存のためだけでなく、古代ゲノムの塩基配列決定に理想的 な DNA 提供源である体毛の保存のためにも、理想的な状況 である。体毛にまだ DNA が残っていれば、そのほぼすべて が体毛のもち主である絶滅種のものであり、骨の場合でよく みられる細菌や菌類由来の DNA ではないことになる。した がって Miller たちは、合計「わずか」41 億塩基対の配列決 定をするだけで、およそ 33 億塩基対のマンモス DNA を得 ることができた。研究チームの試算によれば、マンモスの全 ゲノムはおよそ 47 億塩基対と見積もられ、ヒトゲノムの 1.4 倍の大きさだろうという。

マンモスのゲノムのサイズはヒトゲノムよりも大きいが、 DNA の塩基置換率はヒトゲノムより小さいらしい。塩基置 換率とは、塩基が別の種類の塩基に置き換わつている率の ことで、進化上の変化の尺度になる。マンモスと近縁種の アフリカゾウのゲノム間の置換率はわずか $0.6 \%$ であるこ の值はヒトとチンパンジーの間の置換率のおよそ半分だが、 これら 2 種のゾウは、ヒトとチンパンジーの分岐と同じこ ろか、それよりわずかに早く分岐したと考えられている ${ }^{1}$ 。 ぞういうわけか、ゾウ類の核ゲノムの塩基置換率はヒトと 大型類人猿の間の值よりも小さいのだ。これはミトコンド リアゲノムについても同様で 7 、ヒトと大型類人猿の間の置 換率はやはりゾウ類どうしの值の 2 倍を超えている。核と ミトコンドリアのゲノムは異なる酵素群によって複製され ており、ゾウ類でこの 2 箇所のゲノムがどちらも、ヒトと 大型類人猿の間よりもゆっくりと進化している理由はまだ 明らかになっていない。

今回得られたのはマンモスゲノムの概要配列であり、標準 的な方法で遺伝子を予測するにはあまりにも断片化していて エラーも発生しやすい。それでも Miller たちは、ほかの 50 種の脊椎動物と比べて、マンモスに特有のタンパク質コード 領域をいくつか見つけ出した。こうしたマンモス特有の差異 の存在は、意外なことではない。それぞれの哺乳類種には、 ほかの一部の哺乳類種にはない特有のアミノ酸置換があると
考えられているからである。例えば、ATP2C1 タンパク質の アミノ酸 52 個からなる断片には、マンモスに特有のアミノ 酸置換が 1 つ含まれているが、この断片にはテンレックと フタッユビナマケモノにそれぞれ特有な 2 つのアミノ酸置 換の部位も含まれている。また、タンパク質Clorf190 のア ミノ酸 30 個からなる断片内には、マンモスがほかの有胎盤 哺乳類と異なるアミノ酸の部位があるが、同じ部位でジリス やカンガルーネズミでもアミノ酸置換が生じている。 Miller たちは、見つけたアミノ酸の差異が「表現型効果が生じる可 能性…を有意に高める」ものだと主張しているが、彼らの解 析は、1 個のアミノ酸置換が機能上の結果、もしくは適応上 の価値をもつことを実証したものでは決してない。こうした 疑問に対する解答は、対象となるタンパク質を精査すること でしか得られないのである。

今回のマンモスゲノムからは、絶滅種の全ゲノム塩基配列 決定が実際に可能であることや、そうした種の DNA 塩基配 列には現生動物の配列と比較して違いがあることがわかっ た。では、このほかにいつたい何を知ることができるのだろ うか。多くの概要ゲノムプロジェクトと同様に、あまり多く のことはわからないだろう。しかし、概要ゲノムは物語の序 章にすぎない。ゲノムプロジェクトの主な役目は、その後の 研究のための情報提供源になることであり、このことは最初 のヒトゲノム塩基配列決定を報告した論文 ${ }^{8,9}$ が何千回と引 用されていることからも明らかである。

絶滅種の核ゲノム概要配列として次に手に入りそうなの は、ヒトに最も近いネアンデルタール人のものである。ネア ンデルタール人については、ミトコンドリアゲノムの全塩基 配列が既に公表されている ${ }^{10}$ 。ゲノミクスにおいては、今後 しばらくは研究の多くが、ゲノム塩基配列について完全にそ の機能や生物学的意義を解明することと、全塩基配列を決定 することになるだろう。実際、今回の絶滅したマンモスのゲ ノム塩基配列はもちろんのこと、現生脊椎動物の公表済みゲ ノム塩基配列の大半は、現在のところ概要配列にとどまって いる。しかし将来的にはゲノミクス研究によって、塩基配列 レベルでのどの違いが、マンモスと現生ゾウ類、あるいはヒ トとネアンデルタール人の間で表現型の違いが生じる基盤に なっているのかが解明されることだろう。そのためには、機 能や生物学的意義が十分に解明されたゲノムが必要不可欠な 基礎情報となる。

Michael Hofreiter、マックス・プランク進化人類学研究所 (独)。

1. Miller, W. et al. Nature 456, 387-390 (2008).

2. Sanger, F., Nicklen, S. \& Coulson, A. R. Proc. Natl Acad. Sci. USA 74, 5463-5467 (1977).

3. Margulies, M. et al. Nature 437, 376-380 (2005).

4. Smith, D. R. et al. Genome Res. 18, 1638-1642 (2008).

5. Poinar, H. N. et al. Science 311, 392-394 (2006).

6. Noonan, J. P. et al. Science 309, 597-599 (2005).

7. Rohland, N. et al. PLoS Biol. 5, e207 (2007).

8. International Human Genome Sequencing Consortium Nature 409, 860-921 (2001).

9. Venter, J. C. et al. Science 291, 1304-1351 (2001).

10. Green, R. E. et al. Cell 134, 416-426 (2008). 